\title{
La idea de la guerra: filigranas para su estudio*
}

\author{
The idea of war: filigree for its study \\ Recibido: 10 de enero de 2011 - Revisado: 20 de enero de 2011 - Aceptado: 10 de febrero de 2011 \\ William Ortiz Jiménez ${ }^{* *}$
}

\section{Resumen}

El presente artículo obedece al interés que existe en el ámbito general por escribir sobre temas relacionados con la guerra y el conflicto. La intención es tratar de realizar un análisis diferente sobre la manera en que se ha tratado el asunto de la política y la guerra, desde una mirada sociológica, histórica y política. Como artículo, este se encuentra configurado siguiendo un modelo de escritura metafórica y anecdótica, hasta lograr dar forma a una filigrana de la guerra.

\section{Palabras clave}

Guerra, filigrana, metáfora, conflicto, método.

\begin{abstract}
The present article obeys to the interest that exists in the general scope, to write on subjects related to the war and the conflict. In this case, one is not to repeat the reflections provoked on critical, sociological or political aspects: it is plus to philosophical or literary reflection, with a noticeable political emphasis. Like article, it is formed following a model of metaphorical anecdotal and writing, until attaining to give form to a filigree of the war.

Keywords

War, filigree, metaphor, conflict, method.
\end{abstract}

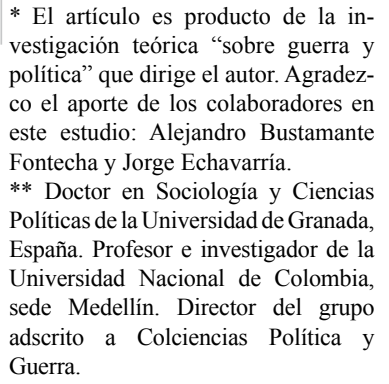

* El artículo es producto de la investigación teórica "sobre guerra y política" que dirige el autor. Agradezco el aporte de los colaboradores en este estudio: Alejandro Bustamante Fontecha y Jorge Echavarría.

** Doctor en Sociología y Ciencias Políticas de la Universidad de Granada, España. Profesor e investigador de la Universidad Nacional de Colombia, sede Medellín. Director del grupo adscrito a Colciencias Política y Guerra. 


\section{Introducción}

Son muchos los estudios, investigaciones y puestas en escena que se han hecho sobre la guerra. Además, son famosos los relatos, disertaciones, metáforas y escritos literarios que la evocan y, muchas veces, ensalzan sin límites. Quizá el tema sea tan apasionante tanto en la literatura como en la política, en la historia como en la sociología. Pero, sin duda, el giro en la manera de analizar los contextos y reflexiones lo hizo Jean Bouthoul al postular un tratado tan extenso y rico en anécdotas e historias, que se convirtió en la guía indispensable para estudios posteriores. La polemología, o tratado sobre la guerra, es una especie de brújula para noveles y expertos. Su contenido emerge de la revisión de los hechos y las disertaciones hechas por el autor para recrear un tema a veces árido pero, otras veces, entretenido. Igualmente, una mirada a la guerra debe partir, indiscutiblemente, de aquellas obras literarias que narraron acontecimientos y situaciones que jamás se olvidarían. Retomamos, en este caso, a La Ilíada o $L a$ Orestíada, para no ir muy lejos. No podíamos dejar de lado los aportes de la filosofía, Nietzsche, por ejemplo, o para el caso nos convocan las metáforas de George Lakoff y Mark Johnson. Este contexto metafórico, histórico, sociológico, literario y político es el que se pretende dar a conocer a los lectores en estas páginas.

\section{Miradas y filigranas}

Es difícil, y muchas veces arduo, referirse a temas tan álgidos y con tantas formas de estudiarlo como es el de la guerra. Para tratar de no hacer el estudio tan tedioso partamos de aquella sentencia que nos hiciera Jomini: "La guerra no es una aberración de la vida humana... sino una parte integral de la historia de la civilización" (Underhill, 1981, p. 11) o aquella otra que advirtiera el padre de la polemología, Jean Bouthoul: "La guerra es la lucha armada y sangrienta entre agrupaciones organizadas [...] la guerra es una forma de violencia que tiene como característica ser metódica y organiza- da en cuanto a los grupos que la hacen y a las maneras como la conducen. Además, la guerra está limitada en el tiempo y en el espacio, y sometida a reglas jurídicas particulares, extremadamente variables según épocas" (Bouthoul, 1984, p. 105), algo así como la lucha violenta nacida entre dos o más agrupaciones de seres pertenecientes a la misma especie, por su voluntad o su deseo.

Pero no nos detengamos en acuñar pensamientos en contextos tan amplios y cenagosos, sino que en su lugar entremos de una vez al tema para el cual hemos decidido tomar como punto de partida del análisis el trabajo de George Lakoff y Mark Johnson (1986), en el que la metáfora será planteada como un recurso estructural y explicativo, que da al pensamiento $\mathrm{y}$ al discurso una organización y una regulación de la que somos casi inconscientes, por lo que al recurrir a esas metáforas podemos determinar cómo vemos el mundo, hasta el punto de que "es como si la capacidad de comprender la experiencia por medio de metáforas fuera uno de los sentidos" (Lakoff y Johnson, 1986, p. 233). Un corolario de ello es la historicidad y relatividad cultural de las maneras de percibir el mundo, ya que las metáforas son uno de los instrumentos con carácter cognitivo que permiten aprehender aquello que determinamos como mundo, en contra de lo sostenido por una corriente dominante de la tradición filosófica, que ve en la metáfora un puro juego lingüístico, y sí en sintonía con el dictum nietzscheano: “¿Qué es entonces la verdad? Un tropel de metáforas, metonimias, antropomorfismos, en resumidas cuentas, una suma de relaciones humanas (...) las verdades son ilusiones de las que se ha olvidado que lo son; metáforas que se han gastado y han quedado sin fuerza, monedas que han perdido su troquel y no se las considera ya como monedas, sino simplemente como metal" (Nietzsche, 1980, 11) ${ }^{1}$.

A manera de puesta en escena, hoy día hay una deriva del término 'guerra' hacia otros aledaños pero no exactamente equivalentes: 
confrontación, conflagración, conflicto (armado), disenso, agresión, polémica, control hostil, enfrentamiento, choque de civilizaciones, entre otros (Estrada, 2004)2. Al tiempo, se multiplica la adjetivación para el propio término 'guerra': civil, no declarada, narco, sucia, invisible, santa, de emancipación, revolucionaria, irregular, justa, fría, de baja intensidad, mediática, global, étnica, religiosa, de guerrillas... Del mismo modo, cambian sus objetivos: contra la pobreza, contra el hambre, contra las drogas, contra la discriminación, contra el analfabetismo, contra la desigualdad, contra el sexismo, etcétera, caso en el que el mismo término 'guerra' indica desde propósitos hasta proyectos políticos coyunturales o de largo plazo, desde cambios de mentalidad frente a determinados aspectos culturales hasta eslóganes de campaña. Estas tendencias dan cuenta del carácter elusivo del término, de un lado, pero también del recurso a las metáforas alternas por donde se encauzan sus explicaciones y determinaciones, y que son provenientes de un sinfín de disciplinas, discursos, prácticas y abordajes teóricos diversos. De todas maneras, tanto las metáforas rutinarias como las de carácter emergente proporcionan una estructura coherente, destacan unos aspectos de la realidad aprehendida y ocultan otros, no como una mera cuestión de lenguaje, sino como motores de nuestra conceptualización, actitudes y acciones.

La sencilla exploración, propuesta por Lakoff, de las tipologías estructurales metafóricas rendiría un sugestivo mapa en el tema que nos ocupa: tomaremos, para este caso, los tres tipos de metáforas anunciadas por él: las metáforas orientacionales ${ }^{3}$, que organizan un sistema de conceptos con referencia a otro sistema, de modo que, por ejemplo, con referencia al eje de orientación espacial, se valora lo Alto y se deprecia lo Bajo, relacionando estas categorías espaciales con criterios de valoración moral: acciones militares viles, o bajas, o rastreras; el uso de "hundirse", "sumirse", "abismarse", "profundizar", para denotar fases de un conflicto, etcétera, con una calificación moral implícita (y al contrario "salir", "ele- varse", "levantarse", entre otras); las referencias que aluden a derecha, centro o izquierda, connotando respectivamente conservadurismo, equilibrio o compromiso social, y otras tantas. En segundo lugar, están las metáforas ontológicas, que caracterizan con una forma particular o fenómeno, hecho, persona, etcétera. De aquí surgirán caracterizaciones de la guerra de largo recorrido: la guerra como origen; como instinto; como destino o sino ineluctable; como medio atmosférico, donde se perciben nubarrones, vientos, tormentas; como maldición; la guerra como madre de todas las cosas en Grecia de la que se deriva la idea moderna de una revolución o insurrección como "partera de la historia"; como guión cultural; como irracionalidad o locura; como tara o enfermedad hereditaria; como recorrido donde hay encrucijadas, naufragios, caminos errados, puntos de partida y llegada. Y, por último, las metáforas estructurales, en las que una actividad o experiencia se estructura en los términos de otra: enfocar esfuerzos para remediar una situación se convierte en una guerra contra algo (el analfabetismo, la ignorancia, la pobreza...), una discusión será un combate o enfrentamiento verbal, entre otras.

Quizá La Ilíada se convirtió en uno de los textos clásicos e inaugurales de la cultura occidental europea propios para iniciar este tipo de estudios sobre la guerra. Ella es el motor de su desarrollo argumental. Es más, la guerra, el conflicto supremo, como no podía ser de otra manera, es un lugar recurrente en las trayectorias vitales de muchos héroes clásicos. Si retomamos el texto, observamos que es un canto a la cólera de Aquiles, en la que unos y otros tienen su papel, pese a que la religión no tenga en ella realmente ninguno. $Y$ es que el mundo griego atendió, en su momento, las esencias de los problemas que se le plantean al hombre de hoy. Se abre allí lo que podríamos denominar un primer surco metafórico para referirse al conflicto bélico, el que tendrá enorme repercusión y prefigurará en adelante los modos de pensar la guerra. Tales trazas metafóricas sirven de espacio de tránsito a explicaciones e interpretaciones durante largos periodos de 
tiempo, como sobrentendidos o prefiguraciones (en el sentido de la noción de mímesis o VorErzählung de Paul Ricoeur) (Ricoeur, 1977, p. 14), esto es, como referentes estabilizados culturalmente en su sentido básico, de obligatoria referencia y aceptados per se, una precomprensión del mundo de la acción, de sus estructuras inteligibles, de sus recursos simbólicos y de su carácter temporal expresado como narración. Desde este punto de vista, una definición intemporal de la guerra a lo Sun Tzu o Clausewitz no tiene mucho sentido ya que esta se configurará sobre matrices metafóricas cambiantes, como veremos a continuación. Ello no quiere decir que la práctica de la guerra no eche mano de recursos y estrategias similares, con las distancias y ventajas que la tecnología plantea, o que su relación con la política, el poder y los Estados no tenga marcas de continuidad, pero esta introducción se preocupa por las construcciones discursivas sobre la guerra, no por sus formas reales en tanto acciones violentas.

Más concretamente, es en el canto XVIII (entre los versos 478 y 614) donde Hefestos forja las nuevas armas para Aquiles, a pedido de su madre, y se despliega la descripción del escudo que el artesano divino fabrica. Esta ékphrasis o descripción poética de un objeto estético hace del escudo una Imago mundi, un conjunto metafórico totalizante del orbe. Está circundado y delimitado por una banda exterior que encierra las representaciones internas ("En la orla del sólido escudo representó la poderosa corriente del río Océano" (pp. 607-608)), las que a su vez van desde los cuerpos celestes hasta el mundo de los hombres, con sus actividades productivas y su vida ordinaria. Específicamente allí se representan dos ciudades, una en guerra y otra en disfrute pleno de tiempos de paz $^{4}$, dos avatares de la vida de la polis. En la ciudad en paz, en medio de lo cotidiano (bodas, danzas...), se dirime pacíficamente un conflicto, donde los contradictores litigan frente al pueblo y los ancianos, quienes expresan sus juicios alrededor de los alegatos y argumentos enfrentados. Del otro lado, la ciudad sitiada por dos ejércitos, uno destructor y otro que solo busca botín, congrega a sus ciudadanos en su defensa, y acuden estos a planear una emboscada en la que puedan obtener ventaja sobre los dos ejércitos que los amenazan. Es evidente la contraposición entre las dos formas de resolver las diferencias: la argumentación y la destrucción o el saqueo, como también los fines perseguidos: en la contienda pacífica, se busca demostrar la justicia "del mejor modo", y ello, aunque enfrenta y divide a los espectadores en bandos de apoyo a uno u otro de los contendientes, los unifica en el fin buscado. Los dos ejércitos, por su parte, tienen fines diversos ("no estaban acordes...") tratando o de destruir la plaza sitiada o de hacer pillaje de sus riquezas. La ventaja que pudieran tener frente a la ciudad es así disminuida, mientras que los ciudadanos, en desventaja, no solo no se rinden sino que su unen en defensa de su polis y planean su estrategia con astucia. Redundemos: la ciudad en paz alberga inevitables conflictos, pero ellos se resuelven de forma incruenta con la finalidad de alcanzar la mejor justicia posible, por lo que los ciudadanos, así se dividan para apoyar una u otra versión, están unidos en búsqueda de tal fin superior. La ciudad, sitiada por la guerra, aglutina a los amenazados en búsqueda de la salvación de su comunidad, mientras los sitiadores, en ventaja por su fuerza, se dividen por la mezquindad cruel de unos objetivos completamente pedestres.

Como vemos, los personajes de La Ilíada no son ajenos a los deseos de rapiña y expolio; Agamenón representa la pasión por el poder; Ifigenia, el triunfo de la razón de Estado; Aquiles, la pugna por la gloria; Áyax, es la fuerza; Ulises hace de la guerra "el arte del engaño" (Sun Tzu, 2001, cap. I). Asimismo, en La Orestíada se encuentra un primer planteamiento de los conflictos de género, saldado entonces en beneficio del varón. Muchas otras historias, como la de los argonautas, encarnarán una visión de la guerra como aventura.

Pensaríamos, pues, que este primer modelo metafórico, labrado de forma excelsa por 
el dios herrero en el escudo del héroe, sugiere que la ciudad, la comunidad humana organizada, para sobrevivir tanto a sus conflictos internos como externos, debe mantenerse unida en torno a ideales excelsos, que pueden lograr imponerse incluso sobre la fuerza de sus atacantes. Estas dos ciudades son, en suma, una sola, que atravesará de forma inevitable momentos de paz o de guerra, pero que debe seguir el guión allí aconsejado para pervivir. Incluso, si prolongamos esta metáfora a partir de la destrucción de Troya, destrucción ejemplarizante que castiga el violar la hospitalidad de Menelao, rey de la guerrera Esparta y marido de la secuestrada Helena, esta ciudad sobrevive a través de Eneas, que, según el relato de Virgilio, será el fundador de las ciudades que, por obra de sus descendientes, llevarán a la fundación de Roma.

El ideal de una ciudad en paz sempiterna, tan cara al Renacimiento ${ }^{5}$, sería desechada desde esta imagen, como que la ciudad enfrenta el conflicto de manera "natural" y sucesiva: la polis es hija del "pólemos", como anota Giorgio Colli (1980, p. 6), y debe saber aceptar esta condición, no importa su magnitud. La comunidad humana, en palabras de otro ilustrado (Kant, 1999, p. 10), está atrapada en una insociable sociabilidad, al tiempo jalonada entre formar sociedad y enfrentar la amenaza permanente de su disolución ${ }^{6}$. En esta vertiente kantiana, será reformulada luego por el mismo filósofo, de modo que la guerra aparecería como prerrequisito para la instauración de la paz: la alternancia del modelo griego es aquí reemplazada por una metáfora de etapas 7 , donde la guerra es lo "natural" que precede inexorablemente a la erección de lo "civilizado", la paz. Desde la perspectiva optimista del utopismo renacentista, sería posible lograr erradicar la guerra, calificada como irracional, al edificar una sociedad absolutamente racional y regulada.

La luminaria del comportamiento guerrero es el surco con el que se emparentan las reflexiones etológicas sobre el innatismo de la agresión, con autores como Irenäus Eibl-Eibes- feldt, Konrad Lorenz o Desmond Morris ${ }^{8}$ o en el pesimista texto producido desde la psicología de Erich Fromm The Anatomy of Human Destructiveness (Fromm, 1973, p. 16), que prolonga la veta pesimista freudiana. Estos polémicos asertos, radicando la agresión en nuestra configuración biológica, mezclan las aguas de términos que definen la agresión desde distintas coordenadas, por lo que el mismo Fromm se verá obligado a separar la agresión, de carácter innato y adaptativo, (para él, de carácter benévolo, evolutivo), de la destrucción y crueldad, de signo malévolo y destructivo. Este modelo metafórico es el mismo que sirve a la antropología materialista de Marvin Harris (2008, p. 7) para establecer diferencias: la guerra no sería innata, instintiva o natural, sino que surge de condiciones materiales concretas, como la escasez de alimentos, de territorio, de animales de caza, de materias primas, siendo entonces un estilo de vida ecológicamente adaptativo. Así, si bien es inevitable una respuesta agresiva para la adaptación y supervivencia, en tanto las condiciones materiales cambiantes la exigen, tarde que temprano esta ya no estaría inscrita en nuestra "naturaleza" individual o en la de la comunidad humana.

La analogía entre guerra y justicia marca otro cauce más donde opera la metáfora y la comprensión que ella brinda: cómo razonar la guerra como un acto justo es una preocupación que viene desde la antigüedad. La misma expedición aquea a Troya es un buen ejemplo: es una guerra moralmente justificada por la ruptura del principio de hospitalidad, que será renovado una vez se destruya la ciudad de donde proviene y se proteja al violentador. Se procuraba conciliar este uso de la fuerza y el derecho, ya sea para que la violencia se ponga al servicio del derecho o para que este la limite. Como en el grabado de los cañones del rey francés Luis $\mathrm{XIV}^{9}$, la guerra es la Ultima ratio regis, una respuesta justa a una agresión no provocada, último recurso para que un derecho violentado se restituya plenamente, recurso final y extremo después de fracasar con los argumentos de la razón. Esta doctrina de la guerra justa, que engendrará 
en nuestros días las limitaciones que impone el derecho internacional humanitario, tiene momentos de auge o de olvido: cuando se invoca la razón de Estado (en los siglos XVII y XVIII o en la era Bush post septiembre 11), las justificaciones legales desaparecen y se considera la guerra o la violencia contra el contrincante como de uso discrecional del Estado presuntamente en peligro como herramienta política. Las expresiones ius ad bellum o ius in bello, que aluden a la justificación para ir a la guerra o para usar la fuerza, y a las limitaciones al ejercicio violento dentro de la guerra misma, respectivamente, comienzan a aparecer en las entreguerras mundiales, mientras que nos es mucho más contemporánea la necesidad de pensar en el post bellum, esto es, el restañar las heridas sociales y los efectos funestos de los conflictos, reparando y resarciendo a las víctimas, persiguiendo y castigando a los victimarios. Ejemplo de ello se puede notar en las acciones de la ONU, la Corte Penal Internacional $\mathrm{y}$, sin ir muy lejos, las del juez español Baltasar Garzón, que procuró el juicio a Pinochet o anda en búsqueda de la cúpula dictatorial argentina o sigue de cerca los procesos con paramilitares en Colombia o los llevados a cabo en Sudáfrica o Guatemala.

Si se les logra dar valor a los denominados surcos metafóricos (o mímesis 1, prefiguración), se entenderá, en resumen, que estas son formas de estructurar de modo coherente nuestra experiencia vital, que nos llevan a proyectar un dominio conceptual sobre otro, a entender una realidad distinta: las metáforas nos permiten entender sistemáticamente un dominio de nuestra experiencia en términos de la otredad, $\mathrm{y}$, al tiempo, nos hacen permanecer atados a estas precomprensiones, lo que dificulta mirar las cosas desde ámbitos que las dinamicen y renueven. Así, es de vital importancia la aparición de nuevas metáforas, que congregan nuevamente las voluntades y modos de entender. El arte, durante mucho tiempo la agencia de producción simbólica, y la publicidad, la industria del entretenimiento, la moda, hoy, son canteras de creación de nuevos registros metafóricos, pero ellos pueden ser forjados también en espacios sociales y culturales diversos: el "New Deal" rooseveltiano ${ }^{10}$ dio forma a un espacio metafórico que permitió remontar la crisis del año 1929 y enfrentar los Estados Unidos exitosamente la Segunda Guerra Mundial; los anuncios publicitarios realizados para Benetton por Oliverio Toscani, y que en su momento enfocaron la guerra de los Balcanes, fueron contundentes en sus imágenes agresivas e ineludibles para mostrar la barbarie de esta guerra étnica; el papel de la transmisión televisiva "en vivo y en directo" de la guerra de Vietnam, de la del Golfo o de la invasión a Irak o del derrumbamiento de los dos edificios del World Trade Center... etcétera, etcétera, todos ellos registros metafóricos de factura y alcance diverso que en su momento proporcionaron referentes de intelección sobre un fenómeno o acontecimiento que emergía de modo retador, y que, por ello mismo, no alcanzaba a ser atrapado por las metáforas en uso

No obstante, quisiera mostrar que del mismo modo que en sus días Homero (ese improbable aeda mítico de cien bocas y nulos ojos, padre fantasmal de todos los que crean con la palabra de ahí en adelante) creó metáforas poderosas para entender la guerra, lo propio ha sido hecho en innumerables ocasiones de ahí en adelante. Se escogerá un tanto caprichosamente a dos autores, León Tolstói (Tolstói, 1987) y Arturo Pérez-Reverte (Pérez-Reverte, 2006): el conde Tolstói, una figura cimera y emblemática; Pérez-Reverte, un escritor con el baldón del "best sellerismo" bien visible" ${ }^{11}$, pero ambos ofreciendo formas metafóricas innovadoras para mirar las guerras que acontecen en sus culturas y en sus mundos histórico-culturales.

Tolstói coincide con la idea de que la guerra es la fábrica de la historia, pero estas no son peleadas como medios para resolver conflictos internacionales o lograr objetivos trazados por una nación, sino que "son el resultado de la convergencia de fuerzas primordialmente irracionales, operando en grados variados de armonía, tensión, coincidencia y conflicto entre 
ellos mismos, mucho más allá de la habilidad de cualquier mente humana para comprender o controlar su despliegue" (Kandutsch, C. (2010). Esta irracionalidad que no responde a los motivos tradicionalmente invocados, de cuño más o menos racional como la protección de fronteras, la expansión territorial, el dominio geopolítico, etcétera, y que Tolstói acuña a finales del siglo XIX, un siglo de guerras entre naciones al que sucede otro siglo con dos guerras globales declaradas, prefigura proféticamente los motivos hoy esgrimidos, resumidos en la consecución a toda costa de la vaga idea de "seguridad", y al modo de guerra contemporáneo más ubicuo y gaseoso, más temible y dañino: el terrorismo. En esta nueva metafórica guerrera, desaparecen términos como 'triunfar' o "victoria' ${ }^{12}$, y los términos que justificaban moralmente la guerra se hacen inaplicables, como que se borra la diferencia entre la acción de guerra ejecutada por las militares regulares y los terroristas, al superponerse extrañamente actos de "barbarie" ejecutados de uno y otro lado, sea que ellos salgan a la luz pública o que se oculten (Abu Ghraib, Guantánamo, Palestina, Operación Cóndor...), ya que "la guerra contra el terror corre necesariamente el riesgo de ser una guerra sucia" (Ignatieff, 2001, p. 17).

Quizá podamos leer a Tolstói desde nuestro hoy, como si profetizara, y a Pérez-Reverte, como si testimoniara. Antes de ser novelista exitoso, de novelas de capa y espada, ejerció como brillante reportero en zonas en conflicto ${ }^{13}$. El protagonista de su novela, fotógrafo de guerra retirado, se encierra en una torre para pintar lo que su cámara no pudo captar:

"El gran panorama circular aún estaba pintado en zonas discontinuas. El resto eran trazos a carboncillo, simples líneas negras esbozadas sobre la imprimación blanca de la pared. El conjunto formaba un paisaje descomunal e inquietante, sin título, sin época, donde el escudo semienterrado en la arena, el yelmo medieval salpicado de sangre, la sombra de un fusil de asalto sobre un bosque de cruces de madera, la ciudad antigua amurallada y las torres de cemento y cristal de la moderna, coexistían menos como anacronismos que como evidencias (...)" (Pérez-Reverte, 2006, pp. 11-12).

Este esfuerzo por obtener esa Imago mun$d i$ guerrera, eco contemporáneo del escudo de Aquiles, sabiéndose técnicamente competente pero no un pintor de genio, que podría ser el indicado para cubrir esos 25 metros circulares por tres de altura, ese intento que desde la cámara lo había llevado infructuosamente a tratar de captar "la materia del mundo de colores, sensaciones y rostros que constituyó su búsqueda de la imagen definitiva, el momento al mismo tiempo fugaz y eterno que lo explicara todo. $\mathrm{La}$ regla oculta que ordenaba la implacable geometría del caos" (Pérez-Reverte, 2006, p.15). Este proyecto abandonado seguía siendo el mismo perseguido con su pintura. "Un panorama mural que desplegase, ante los ojos de un observador atento, las reglas implacables que sostienen la guerra - el caos aparente - como espejo de la vida. Aquella ambición no aspiraba a obra maestra; ni siquiera pretendía ser original, aunque en realidad lo fuese la suma y combinación de tantas imágenes tomadas a la pintura y a la fotografía, imposibles sin la existencia, o la mirada, del hombre que pintaba en la torre. Pero el mural tampoco estaba destinado a conservarse indefinidamente, o a ser expuesto al público. Una vez acabado, el pintor abandonaría el lugar y este correría su propia suerte. A partir de ahí, quienes iban a continuar el trabajo serían el tiempo y el azar, con pinceles mojados en sus propias, complejas y matemáticas combinaciones. Eso formaba parte de la naturaleza misma de la obra" (Pérez-Reverte, 2006, p. 18).

De resultar irrefutable la tarea del cojo herrero Hefesto ${ }^{14}$ y tiene éxito, tal vez porque como dios puede elevarse y mirar las obras humanas desde lejos, proponiendo esa metáfora oscilante de la condición humana, Faulques, el exfotógrafo de combate, no puede totalizarla a sabiendas: ni sus dispositivos fotográficos ni sus habilidades (ni las de ningún otro ser hu- 
mano) pueden ir más allá de superponer fragmentos discontinuos, agrietados, donde la ley que ordena el caos es la misma que lo destruye. En un mundo que ha devenido "escenografía pura", como le dice una de sus amigas, Olvido Ferrara, y continúa: "Cada cual puede elegir cómodamente la parcela de horror con la que decorar su vida conmoviéndose. ¿No crees? Qué lejos estamos, date cuenta, de aquellos antiguos retratos pintados, cuando el rostro humano tenía alrededor un silencio que reposaba la vista y despertaba la conciencia. Ahora, nuestra simpatía de oficio hacia toda clase de víctimas nos libera de responsabilidades. De remordimientos". (Pérez-Reverte, 2006, pp. 19-20). Faulques busca la regla, la geometría tras el caos, "el punto desde el que podía advertirse, o al menos intuirse, la maraña de líneas rectas y curvas, la trama ajedrezada sobre la que se articulaban los resortes de la vida y la muerte, el caos y sus formas, la guerra como estructura, como esqueleto descarnado, evidente, de la gigantesca paradoja cósmica" (Pérez-Reverte, 2006, pp. 19-20).

Como Picasso, Faulques quiere hacer un nuevo Guernica, pero aún más ambicioso, que desentraña de una vez por todas a la guerra, en un sentido platónico, esencial, y no solo a una de sus muchas escaramuzas. Pero está condenado al fracaso, y ello es así porque estamos en un mundo saturado de imágenes retocadas, biempensante y por ello desculpabilizado, en un mundo que ya no se puede explicar las desavenencias entre dioses y hombres o entre hombres que rompen sagrados pactos, que ahora se acoge a la incierta lógica del caos, donde "causas mínimas, inapreciables a simple vista, daban paso a espantosos desastres" (Pérez-Reverte, 2006, p. 202). Pero, tal vez no fracasa.

Asimismo como Tolstói aprehende una guerra que habría de darse plenamente en el futuro, nuestro presente, Pérez-Reverte vuelve a la inmemorial idea, que Aquiles o Héctor entenderían cabalmente, de que para explicar la guerra en nuestro particular presente es necesario volver a entenderla como la más depurada expresión de la vida misma, su quintaesencia, como "la vida llevada a extremos dramáticos" (Pérez-Reverte, 2006, p. 203), una especie de espacio natural de lo humano. Markovik, exsoldado croata y su contrincante, lo resume así: "¿Sabe lo que creo después de mirar sus fotos?... Que en guerra, en vez de que la cámara sorprenda a la gente normal haciendo cosas anormales, lo que hace es lo contrario. ¿No le parece? (...)” y Faulques corrige: "En la guerra se ve a gente normal haciendo cosas normales" (Pérez-Reverte, 2006, p. 159). Así, "lo normal no es el día a día pacífico, sino el estado de guerra" (Grohmann, A. 2007). Los ecos rousseaunianos, de Freud, de Locke, son evidentes: para explicar el presente, la guerra como ese volver al pasado oscuro y siempre queriendo ser olvidado, pasado que nos pasa cuenta de cobro con el costo de la civilización: la desmemoria de nuestra crueldad imbatible, la necesidad de someterse a la caprichosa ley humana para no destrozarnos los unos a los otros.

¿Algún final para el cartabón de las ideas metafóricas? Creo que no. Las imágenes y metáforas no avanzan o se suceden las unas a las otras. Coexisten y sugieren formas de pensar, dominan un tiempo y luego pasan tras bambalinas, esperando nuevamente su turno. Así, la distancia temporal entre Pérez-Reverte, Tolstói y Homero nada dice acerca de un progreso, un acercamiento a la añorada y elusiva almendra del fenómeno: solo reiteran que recurrimos a metáforas para pensar y actuar, y que el ser conscientes tanto de ellas como de la posibilidad de cambiarlas, renovarlas, suplantarlas, es lo que nos hace lo que somos, seres atrapados en el lenguaje, atravesados por las imágenes no siempre consoladoras de nuestras metaforologías, constelaciones retóricas en las que vivimos, con las que explicamos y nos explicamos.

\section{Notas}

${ }^{1}$ Otros nombres que se unen a esta exaltación de la metáfora serían Hans G. Gadamer, Paul Ricoeur, Max Black (Modelos y metáfo- 
ras, 1966, Madrid: Tecnos) y Nelson Goodman (de tradiciones y escuelas diversas).

${ }^{2}$ Este estudio partirá de una base más amplia, la de la retórica, para interpretar los diversos discursos sobre la guerra.

${ }^{3}$ Se recomienda leer el trabajo de Jaime Nubiola, de la Universidad de Navarra, España, 'El valor cognitivo de las metáforas', publicado en Pérez-Ilzarbe, P y Lázaro, R. (eds.), (2000). Verdad, bien y belleza. Cuando los filósofos hablan de los valores, Cuadernos de anuario filosófico, 103, Pamplona, pp. 73-84.

${ }^{4}$ Una buena alegoría al respecto aparece en la traducción de Luis Segalá y Estalella (1910). Recuperado de http://es.wikisource.org/ wiki/La_Iliada. Narra cómo en una de las ciudades celebraban bodas y festines en las que las novias salían de sus habitaciones y eran acompañadas por la ciudad a la luz de antorchas encendidas, se oían repetidos cantos de himeneo, jóvenes danzantes formaban ruedos, dentro de los cuales sonaban flautas y cítaras, y las matronas admiraban el espectáculo desde los vestíbulos de las casas y la otra ciudad aparecía cercada por dos ejércitos cuyos individuos, revestidos de lucientes armaduras, no estaban acordes; los del primero deseaban arruinar la plaza y los otros querían dividir en dos partes cuantas riquezas encerraba la hermosa población.

${ }^{5}$ Se podrá tener más referencias sobre él en More, T. (1516). Utopia; Campanella, T. (1602). La ciudad del sol; Bacon, F. (1627). La nueva Atlántida (de todas ellas hay ediciones españolas), y en los siglos XVII y XVIII, obras como las de De Foigny, G. La Terre australe connue; Vairasse, D. Histoire des Sévarambes, o De Patot, T. Aventures de Jacques Massé, entre muchísimas otras.

${ }^{6}$ Norbert Elias (1981) hace referencia en los siguientes términos: "La civilización —el tema que me ocupa aquí- nunca está del todo finalizada y siempre corre peligro. Está en pe- ligro porque mantener una postura civilizatoria en una sociedad requiere un grado de autodisciplina relativamente alto, y requiere también algo más: es necesario un alto grado de pacificación en la sociedad. Pero, a su vez, la pacificación interna de una sociedad está también en peligro. En peligro por las tendencias de la sociedad misma" (en Ästhetik und Kommunikation, 43, pp. 5-12).

${ }^{7}$ Kant lo sintetiza muy bien con los siguientes argumentos: "La paz entre hombres que viven juntos no es un estado de naturaleza - status naturalis-; el estado de naturaleza es más bien la guerra, es decir, un estado en donde, aunque las hostilidades no se han declarado, sí existe una constante amenaza de que se declaren. Por tanto, la paz es algo que debe ser «instaurado»; pues la omisión de hostilidades no es todavía garantía de paz y si un vecino no da seguridad a otro (lo que solo puede suceder en un estado legal), cada uno puede considerar como enemigo a quien le haya exigido esa seguridad". (Leer la obra citada. Kant, I. (1795). Hacia la paz perpetua, en Reiss, H. (ed.). (1999). Kant: Political Writings. Cambridge: Cambridge University Press.

${ }^{8}$ Eibl-Eibesfeldt, I. (1987). Amor y odio. Barcelona: Salvat; Lorenz, K. (1971). Sobre la agresión, el pretendido mal. Madrid: Siglo XXI Editores; Morris, D. (2003). El mono desnudo. Barcelona: DeBolsillo.

${ }^{9}$ Ejemplo que siguen Federico el Grande de Prusia y la artillería española.

${ }^{10}$ Franklin D. Roosevelt prometió en un discurso de su campaña electoral "un nuevo trato para el pueblo estadounidense": pronunció por primera vez la expresión New Deal a lo largo de su discurso en la Convención Demócrata de Chicago en 1932.

${ }^{11}$ Pérez-Reverte, A. (2006). El pintor de batallas. Alfaguara. Una reflexión de su larga labor como corresponsal de guerra en Sarajevo, 
Etiopía y El Salvador. Para ello nos cuenta la historia de Faulques, fotógrafo especializado en temas bélicos que decide encerrarse en un viejo faro de la costa española para pintar un mural circular que resuma todas sus experiencias. Ahí, mientras Faulques trabaja, recibe la sorpresiva visita de Ivo Markovic — un miliciano croata al que alguna vez fotografió-, quien dice estar desde hace años buscándolo para matarlo.

${ }^{12}$ Se prefiere "terminar exitosamente", "salir del conflicto"... etcétera, con lo que el cierre definitivo se prevé como inalcanzable, lo mismo que el supuesto dominio que habría de lograrse sobre el contrincante: Max Boot wrote: "Win is a word that Obama avoided... [Obama] spoke of wanting to 'end this war successfully' but said nothing of *winning the war*". Bacevich, A. No Exit, The American Conservative, http://amconmag.com/article/2010/feb/01/00006 (accessed on 4th December, 2009) in Kandutsch (2010, nota 4, p.18).

${ }^{13}$ El catártico Territorio comanche. Pérez-Reverte, A. (2001). Madrid: Alfaguara, convertido también en película.

${ }^{14} \mathrm{Su}$ obra está relacionada con todo lo concerniente al trabajo con el metal y debido a la naturaleza mágica de fuego en él. Creen los griegos, que las armas hechas por Hefesto tienen poderes. Además, que hizo las sandalias y el casco alado de Hermes y un cinturón a Afrodita. Asimismo, el cinturón personal de Agamenón, la armadura de Aquiles, los badajos de bronce de Hércules, el carr

\section{Referencias}

Arendt, H. (2005). Sobre la violencia. Alianza Editorial, Madrid.

Aron, R. (1996). Pensar la guerra, Clausewitz. Vol. II. Ministerio de Defensa, Madrid.

Ballesteros Martín, M. (2010). La estrategia de seguridad y defensa. Monografía n. ${ }^{\circ} 67$ del Ceseden. Fundamentos de la estrategia para el siglo XXI.

Beck, U. (2002). La sociedad de riesgo global. Madrid: Editorial siglo XXI.

Bouthoul, G. (1984). Tratado de polemología. Madrid: Ediciones Ejército.

Clausewitz, C. (1999). De la guerra. Madrid: Ministerio de Defensa.

Colli, G. (1980). La sapienza greca. Vol. 3. Milán: Adelphi.

D’Ors, Á. (1954). De la guerra y de la paz. Madrid: Editorial Rialp.

De Salas López, F. (1983). La utopía de la paz y el terror de la guerra. Madrid: Servicio de Publicaciones del EME. Editorial Adalid.

Eibl-Eibesfeldt, I. (1987). Amor y odio Barcelona: Salvat.

Estrada Gallego, F. (2004). Las metáforas de una guerra perpetua. Estudios sobre pragmática del discurso del conflicto armado colombiano. Medellín: EAFIT.

Freund, J. (1985). Sociología del conflicto. Madrid: Ediciones Ejército.

Fromm, E. (1973). The Anatomy of Human Destructiveness (1973). New York: Holt, Rinehart and Winston.

Gadamer, H. y Ricoeur, P. (1966). Max Black. Modelos y metáforas. Madrid: Tecnos.

Grohmann, A. (2006). 'Sobre guerra e hybris' en El pintor de batallas de Arturo PérezReverte. Madrid: Alfaguara.

Grohmann, A. (2007). 'Sobre guerra e hybris en El pintor de batallas, de Arturo Pérez- 
Reverte' in DISSIDEnCES. Hispanic Journal of Theory and Criticism 3.1, p. 5

Harris, M. (2008). Vacas, cerdos, guerras y brujas. Madrid: Alianza.

Hart, L. (1989). Estrategia de la aproximación indirecta. Ministerio de Defensa. Madrid.

Homero (1996). La Ilíada. Madrid: Editorial Alba.

Howard, M. (1987). Las causa de los conflictos y otros ensayos. Madrid: Ediciones Ejército.

Ignatieff, M. (2001). 'Nihilismo apocalíptico'. Revista de Occidente, 246, Madrid.

Kaldor, M. (2001). Las nuevas guerras. Barcelona: Editorial Tusquets.

Kandutsch, C. (2010). 'Mechanisms of Power in the Age of Terrorism' in CTheory, 33 (1-2). pp. 1-20. Recuperado de http:// www.ctheory.net

Kant, I. (1999). Idea de una historia universal en sentido cosmopolita (1784) en Reiss, H. (ed.). Kant: Political Writings. Cambridge: Cambridge University Press.

Keegan, J. (1991). La máscara del mando. Ministerio de Defensa, Madrid.

Lakoff, G. y Johnson, M. (1986). Metáforas de la vida cotidiana. Madrid: Cátedra.

Lorenz, K. (1971). Sobre la agresión, el pretendido mal. Madrid: Siglo XXI Editores.

Maquiavelo, N. (1980). El príncipe. Bogotá: Círculo de Lectores.

Maquiavelo, N. (2000). Discursos sobre la primera década de Tito Livio. Madrid: Alianza.

McFate, M. (2005, noviembre-diciembre). JD. 'Antropología y contrainsurgencia: la histo- ria extraña de su relación curiosa'. Military Review (Publicaciones iberoamericanas).

Morris, D. (2003). El mono desnudo. Barcelona: DeBolsillo.

Nietzsche, F. (1970). Sobre verdad y mentira en sentido extramoral. Obras Completas, vol. I. Buenos Aires: Ediciones Prestigio.

Nubiola, J. 'El valor cognitivo de las metáforas'. En: Pérez-Ilzarbe, P. y Lázaro, R. (eds.). (2000). Verdad, bien y belleza. Cuando los filósofos hablan de los valores. Cuadernos de Anuario Filosófico, 103, Pamplona.

Passerin D'entrèves, A. (2001). La noción de Estado. Barcelona: Ariel.

Pérez-Reverte, A. (2006). El pintor de batallas. Madrid: Alfaguara.

Ricoeur, P. (1977). La metáfora viva. Buenos Aires: Megápolis.

Sabine, G. (1992). Historia de la teoría politi$c a$. Bogotá: F.C.E.

San Agustín. (2002). La ciudad de Dios. Barcelona: Folio.

Sartori, G. (1992). Elementos de teoría política. Madrid: Alianza.

Schmitt, C. (1988). El concepto de lo político. Madrid: Alianza.

Schmitt, C. (2004). Teólogo de la política. Héctor Orestes Aguilar (prólogo y selección de textos). México: F.C.E.

Serrano Gómez, E. (2002). Consenso y conflicto: Schmitt y Arendt. La definición de lo politico. Medellín: Universidad de Antioquia.

Sternberger, D. (1992). Dominación y acuerdo. Barcelona: Gedisa. 
Sun Tzu. (2001). El arte de la guerra. Albert Galvany (Trad.). Madrid: Editorial Trotta.

Toffler, A. y Toffler, H. (1994). Las guerras del futuro. Barcelona: Ediciones Plaza \& Janés.

Tolstói, L. (1987). Guerra y paz. Madrid: Aguilar.

Underhill, F. (1981). Las sociedades modernas $y$ modernizadas. El futuro de los conflictos. (Monografías del Ceseden).

Viroli, M. (2000). La sonrisa de Maquiavelo. Barcelona: Tusquets.

Weber, M. (1987). Economía y sociedad, 8. ${ }^{\mathrm{a}}$ reimpresión. México: F.C.E.

Zorgbibe, C. (1997). Historia de las relaciones internacionales. Madrid: Alianza Editorial. 